\title{
Risk Management in Islamic Banking
}

\author{
REYADH NOFAN SAID AL-ADWAN \\ Senior Lecturer: Islamic Business School \\ College of Business, Universiti Utara Malaysia Kedah, Malaysia \\ Email: ryaedaladwan@gmail.com \\ Tel: +60162003944
}

\begin{abstract}
On the basis of the principles established in Shari'ah, financial services impact both risk management and the financial system supervision. In the context of Islamic financial institutions around the globe, proficient risk management has increasingly gained importance in their attempts to adapt to the challenges and issues brought about by globalization. In this study, the researcher aimed to provide an insight into the major challenges faced by Islamic banks in their quest for development in the current global financial system. It also attempted to determine specific and general risks faced by banks in general and in their institutionalization. Moreover, this paper also stressed on the development and enhancement of current financial tools and organizational planning that facilitate sufficient and effective operational environment for Islamic financial institutions.
\end{abstract}

Key Words: Proficiency, Organizational Planning, Institutional Risks, Operational Environment.

\section{Introduction}

Islamic banks have experienced increasing proliferation around the globe, particularly, where countries including Sudan, Pakistan and Iran have fully implemented Shari'ah laws. In other Muslim countries like Kuwait, Egypt, Jordan, the UAE, Saudi Arabia, Malaysia, Brunei and Indonesia, both Islamic and standard banks co-exist and are run next to each other. In this regard, Islamic banks and standard banks operations are conducted in two different ways - first, to open an Islamic financial department in standard banks and second, to build separate standard bank branches, operating under Islamic Shari'ah. Such branches are different from the normal standard banking in that they depend on Shari'ah as their financial services references. The Islamic financial services industry is comprised of several institutions that range from business and venture banks, mutual insurance firms, and investment firms. Nevertheless, the basis of financial services and maintenance in majority of Islamic countries is formed by banks indicating the significance of risk management in Islamic banks. Several issues to end requires to be addressed, with the most challenging of which is the various methods used by Islamic banks to offer funds that could incur risks. In this regard, the permitted Islamic funding methods provided by these banks are the combination of the profit loss sharing methods as well as the non-profit loss sharing method. Both methods incur various issues, such as risk measurement, collateral sufficiency, and income recognition. These issues call for solutions and effective risk management implementation to reflect the unique features of the Islamic financial services and products. The present research identifies and examines these issues.

\section{Islamic Banks and their Surrounding Risks}

The distinct qualities and methods employed in Islamic financing are accompanied by unique risks that require consideration to assist in developing suitable risk management. For instance, the profit loss sharing (PLS) modes call for special consideration as they are characterized by a great level of risk. This is 
especially true when PLS models shift the immediate risk of Islamic banks to investment depositors, in which case they raise the amount of risk of the banks' assets. In other words, PLS modes make Islamic banks susceptible to risks often shouldered by the equity investors as opposed to debt owners for the following reason, among others;

1. PLS modes management is more complicated compared to traditional financing and the former calls for various transactions that are not easily done through traditional banks; e.g. determining profit/loss sharing ratios on different investment developments within multiple sectors of the economy, and the continuous auditing of financed projects in order to ensure effective governance.

There are also different transactions conducted by Islamic banks like those that provide funds via the PLS and non-PLS modes.

Granting funds through the PLS service mode, particularly in the case of Mudarabah contracts and transactions, confirms no default on the side of the entrepreneurs until the PLS contract expires. In this case, the parties share the low profit or loss based on the predetermined PLS ratios.

In addition to the above, Islamic banks are not legally authorized to advice the entrepreneur administering the business via Mudarabah contracts, and thus, the entrepreneur has the autonomy to run the business based on his preferences and personal decisions. Banks only have the right to share profit or loss from the manager based on the ratio agreed upon in the contract. On the other hand, in direct investment contracts or Musharakah transactions, the bank has a more ample opportunity to control the business because the partners in the contracts are authorized to use their voting rights if they want changes made. Thus, in Islamic finance, the PLS modes cannot be considered as whole and inclusive of guarantees in order to minimize the level of risk and while some operational risks are explained above, the following may be the reasons behind them;

a. Unique transactions that needs to be performed by Islamic banks;

b. Lack of proficient and secure Shari'ah-based legislative system for contract enforcement;

c. Non-existent nature of certain Islamic products.

Added to the above risks attributed to the PLS modes of Islamic financing, non-PLS modes also have distinct risks attached to them that should be enumerated. This holds true particularly in purchases with deferred deliver in what is known as Salam contracts - such contracts expose Islamic banks to commodity price and credit risks. Specifically, in Salam contracts banks guarantee to buy the services on a later period - although payment is presently submitted, the service is held off until the payment is transformed into cash. A similar risk is also notable in leasing or ijarah. In this type of arrangement, the Islamic banks do not have the authority to express significant risks and rewards to the lessee as the leased assets should be documented on the banks balance sheet for throughout the lease duration.

It is evident that the risks innate in the Islamic banks operations stem from the liability side and the unique nature of investment deposit. Stated differently, the rate of return and capital value are not fixed and determined. This characteristic along with the unequal information stemming from the unrestricted PLS and non-PLS agreements provide banks the autonomy to run people's deposits. This poses a considerable potential for moral danger and it produced increased inclination towards risk taking and operating Islamic banks and financial institutions in situations even when assets are insufficient.

\section{The General Risks Enclosing Islamic Banks}

There are also further aspects of the Islamic banks that leave their transactions susceptible to increased risks and less profit compared to traditional banks. The following statements enumerate some of the aspects; 
a. Lack of risk fabrication tools - the prohibition of riba in Islamic banks and the entertainment of other issues of jurisprudence in the interpretation of the term 'gharar' indicates that several risk fabrication tools based on traditional tools, like alternatives, futures, and forwards are not usable in Islamic banks.

b. Islamic banks follow the profit-sharing principle, upon which an undersized money market and government guarantees are based. In this context, liquidity administration is riddled with complexity, particularly in diverging asset-liquidity and maximizing liquidity stocks. In the context of Iran, significant developments have been made for short-term tools and government securities for specific issues such as National Participation Certificates, Central Bank Musharakah.

c. Complication is attributed to liquidity management in light of non-correspondence to the asset liquidity and increasing liquidity shocks.

d. Islamic banks have confined access to contact-lender-of-last resort (LOLR) services and are instead linked with the prohibition of interest and discount rates.

e. Islamic banks have traditionally held a considerable percentage of their assets in reserve accounts in central banks or in corresponding accounts, which influences their profitability as central banks do not provide minimum or no-return for the accounts. Additionally, this impacts Islamic banks competitiveness and maximizes the potential for peripheral shocks coupled with penalties.

\section{Reducing Special Risk faced by Islamic Banks}

According to the above discussion and consideration, Islamic financial institutions can effectively and efficiently deal with risk management by developing an approach based on a suitable regulatory disclosure structure and sufficient development of institutions. The major elements required to guarantee the Islamic banks smooth and effective operations are capital and loss, offsetting reserves and suitable risk control as these may result in;

a. Decreasing the potential for moral vulnerability in PLS modes, where it is important for bankers to hold reasonable amount of their own capital exposed to risk;

b. According to the asymmetric data obtained for limitless contracts (e.g. Mudarabah), depositors are provided with psychological assurance from ample capital and reserves in order to maintain their confidence against potential loss incurred by the performance of individual banks.

c. Increasing the ability of the banks to attract uncompensated demand deposits. On the bank's perspective, these deposits may add to the same risks as asset deposits.

d. Avoiding a continuous destruction of investment deposits in case of loss, which may lead to liquidity chaos, the kind of which Islamic financial institutions are not well-equipped to deal with.

e. Taking into consideration that that PLS and non-PLS modes of financing cover distinct categories of risks that need consideration and monitoring on the basis of the accurate nature of the contracts and the environment as a whole.

Moreover, sufficient funds that counteract loss could profitably be viewed in an inclusive risk management frame by Islamic banks. These should be viewed to the whole operation of financial banks in an Islamic environment and to an appropriate disclosure establishment for Islamic financial institutions. Added to this, Islamic banks and financial institutions require a suitable information system coupled with an effectively organized accounting system for regulation and in order to help the market in countering non-transparency, a feature innate in some Islamic financial goods. This would in turn help shed a light on the special risks 
attributed to the operations of Islamic banks. In order to tackle these issues and to minimize the risks of Islamic bank operations, it is pertinent to focus on some focal issues including;

\section{Capital Adequacy}

Capital adequacy is gauged on the basis of the volume of risk assets. Theoretically, most of the Islamic financial institutions assets should comprise of PLS mode, which is primarily uncollateralized. These assets are attributed to more risks in comparison to non-PLS modes which are collateralized in theory. As a consequence, the percentage of riskier assets to total assets should generally be of higher level in an Islamic framework compared to that of traditional banks and as such, the capital adequacy standard in the former should be stressed. Specifically, it should be kept into consideration that in application, PLS modes only make up a small proportion of the total assets of Islamic banks (for instance, aggregate data reveals that Mudarabah and Musharakah assets constitute $25 \%$ of the Islamic financial institutions operations. In other words, majority of the assets in Islamic banks consist of non-PLS modes - this holds true particularly for mark-up transactions. Thus, it is reasonable to contend that the capital adequacy assessment should not be based only on the thorough evaluation of the risk level of each bank file, but also on the evaluation of the combined PLS and non-PLS mode assets.

\section{Asset}

Mudarabah contracts assets in the Islamic financial system cannot be slotted into categories until the expiration of the original contracts and as such, until then no identifiable default or negligence can be attributed to the part of the agent. As mentioned, PLS transactions default translates to failure of the investment project to deliver as expected in terms of profit or loss. As a consequence, it would be appropriate to keep track of PLS assets that are expected to deliver a certain amount of profit prior to the expiration of contracts.

\section{Management}

Financial institution management is assessed based on the following factors; leadership, technical capability, planning ability to suit dynamic conditions, and the readiness to meet the needs of the community. These factors should be considered in Islamic financial institutions and in this regard, risk control and contract legalization plays a key role in the efficient risk management owing to the dynamic nature of Islamic banks and their operations, supervision over investment projects, organization of assets at certain periods, and the legal reservations of the Shari'ah system.

\section{Earnings}

Earnings are linked to the ability of the bank to make up for losses and to front sufficient capital, and to earning trends. They are deemed to be of high quality if they are sufficient to cover the losses and the accumulation of capital for banks expansion. These two considerations are applicable to Islamic banks. In an Islamic financial institution, losses would first lead to depreciation of the deposits value, after which it impacts the institution's equity position. This is the case if the bank uses its personal resources to counter the losses of a particular project; for instance, in Musharakah. The above risks could result in a liquidity crisis and issues concerning solvency.

\section{Liquidity}

Liquidity is gauged through the deposits instability, through whether or not assets may be exchangeable with cash, and thorough access to the money market including interbank or cash suppliers (lender of last resort). As stated, Islamic banks have limited resources and opportunities to obtain funds through LOLR facilities compared to their traditional counterparts. Nevertheless, Islamic banks are obliged to meet the 
deposit the depositor's demand while traditional banks are not. In sum, the adequacy of Islamic banks liquidity could be enhanced through an organized liquidity arrangement.

\section{Sensitivity to Market Risk}

This is evaluated by the level of acceptance to the changes in market prices, and in that they are similar to interest rates, exchange rates, equity values and commodity prices. To some extent, similar concepts are also held valid in Islamic banks. But according to the interest prohibition stipulated in Shari'ah, Islamic banks are impacted by interest rate risks indirectly in case of price mark-up of postponed sale and leasebased transactions. On the other hand, Islamic banks are openly susceptible to commodity price risk because they bear inventory items, i.e. in mark-up or leased transactions. They are also susceptible to equity price risk compared to their traditional counterparts owing to the Islamic banking nature where equity is financed through PLS modes. Moreover, Islamic banks are exposed to risks associated with exchange rate as traditional banks are. On the contrary, Islamic banks possess fewer risk hedging prospects compared to conventional ones because the according Shari'ah views risk hedging tools like future risks, swap contracts and options are out of reach of Islamic banks at the current Islamic financing condition.

\section{Suitable Clear Information Strategy}

Islamic banks require a clear information system more than the traditional banks owing to the PLS methods influence on depositors and the need for such investments to support the Islamic banking foundation. The more depositors demand, the more information is revealed concerning the bank's strategy. This makes it necessary to facilitate depositors' monitoring of banks' operations and performance. More importantly, in an Islamic banking system, depositors are incentivized to monitor bank operations compared to those in conventional banks since in the former system, the bank performance directly impacts depositors. Monitoring thus ensures that depositors that the return paid to them is a direct representation of the PLS mode's application. This is the fundamental core of Islamic financial institutions and it minimizes the possibility of asymmetric information and in turn, the possibility of selection and moral hazard. This system has the following advantages;

a. Helps in the selection of specific banks in which depositors can allot their funds on the basis of its performance;

b. Provides clear information system that supports depositors and considers their diversified portfolio;

c. It discloses information regarding major factors of risk linked with investment portfolio;

d. It provides internal controls and good management that lessens the occurrence of mismanagement and bring about market confidence in banks;

e. It provides depositors with the expected rate of return;

f. It provides the depositors with information concerning the education and professional background of management and staff to increase their confidence in the bank.

\section{The General Risk Factors in Islamic Banks}

Several factors lead to increased risks faced by Islamic bank operations and hence, lessen their profits compared to conventional banks; some of these factors are enumerated below;

a. Lack of money markets - there is a need to establish a liquidity system in the Islamic money market for Islamic banks, whether domestic or international, which is according to the Shari'ah principles.

b. Lack of accessibility and availability of LOLR facilities - this limitation is related to the prohibition of discount rates and this can be logically resolved by developing extensive accessibility of Islamic financial institutions to trustworthy money markets. 
c. Legal reservations and confined market infrastructure that limits the accessibility towards hedging tools - the lack of legal structure can lead to an ineffective market development and increased risks to operations. For instance, the issue concerning whether imitative or future contracts can be utilized for risk minimization in Islamic financial transactions is still unresolved. This may also be attributed to the consistency of religious principles that need further investigation.

\section{Concluding Remarks}

The ultimate basis for the above discussed considerations pertaining to the development of Islamic financial system is an Islamic financial regime, which could compete hand in hand with international conventional financial institutions. Among the major pillars that need to be established to support international and domestic financial system is the development of a standardized managerial and regulatory structure that is aligned with international good practices for banking institutions and non-bank financial entities. In this regard, institutions and organizations like the Islamic Development Bank can play a key role in developing and supporting Islamic financial institutions and facilitate the dissemination of information on the discussed issues to global members. Specifically, the issues that require consideration include;

a. The requirement for a standardized managerial and regulatory structure for Islamic banks;

b. Risk management issues and procedures addressing risk weight of assets;

c. Liquidity management, capital adequacy and issues pertaining to assets control in Islamic banks;

d. Superior governance and profitability issues; and lastly,

e. The adoption of new financial modes by Islamic banks.

\section{References}

Accounting and Auditing Organization for Islamic Financial Institutions, "Statement on the Purpose and Calculation of Capital Adequacy Ratio for Islamic Banks", Bahrain, AAOIFI, 2001.

Ahmad, Ausaf, "Development and Problems of Islamic Banks", Jeddah , Islamic Development Bank (IRTI), 1987.

Allawi, Luay, "Leasing: an Islamic Financial Instrument" Islamic Banking and Finance, (Conference Paper), London, Butterworths, 1986.

Bashir, Abdel-Hamed Mahmud, "Profit Sharing Contracts with Moral Hazard and Adverse Selection", American Journal of Islamic Social Science, Vol. 7, No. 3, 1990.

Beattie, Vivien and Casson, Peter, et al. (eds), "Banks and Bad Debts: Accounting for Loan Losses in International Banking”, New York, John Wiley \& Sons, 1995.

Channon, Derek, British Banking Strategy and International Challenges, London, Macmillan, 1997.

Chapra, Umar and Khan, Tarighullah, "Regulation and Supervision of Islamic Banks", Occasional Paper, No. 3, Jeddah, Islamic Development Bank, 2000.

Errico, Luca and Farahbakhsh,, Mitra, "Islamic Banking Issues in Prudential Regulations and Supervision”, IMF Working Paper 98/30, Washington DC, IMF, 1998.

Faruqi, Muhammad, "Islamic Banking and Investment: Challenge and Opportunity", Columbia, Columbia University Press, 1996.

Ford, J., and Mullineux, A., "Financial Information and Monetary Aggregates in the UK", Discussion Paper, No. 95-01, UK, University of Birmingham, 1995.

Ford, Jim and Makiyan, Nezamuddin, "Portfolio Behavior of Islamic Banks: A case Study for Iran" Discussion Paper, No. 99-01, UK, Birmingham University, 1997.

Franks, J. and Broyles, J.E., Modern Managerial Finance, Chichester, Wiley, 1979.

Hoyle, Julia and Whitehead, Geoffrey, Elements of Banking, Oxford, Made Simple Books, 1987.

Hull, John, Options, Futures and other Derivative Securities, London, Prentice Hall, 1989.

Islamic Development Bank (IRTI), "Risk Management: An Analysis of Issues in Islamic Financial Industry”, Occasional Paper, No. 5, Jeddah, 2001. 
Jackson, Patricia, "Risk Measurement and Capital Requirements for Banks", Bank of England Quarterly Bulletin, May 1995.

Kane, Edward, and Buser, Stephen, "Portfolio Diversification at Commercial Banks", Journal of Finance, Vol. 34, No. 1, 1979.

KHAN, Mohsin and Mirakhor, Abbas, "Monetary Management in an Islamic Economy", Journal of Islamic Banking and Finance, Vol. 10, 1993. Journal of 54 Islamic Economics, Banking and Finance.

Mishkin, Frederic, “the Economics of Money, Banking and Financial Markets”, New York, Harpercollins Publisher, 1995.

Nienhaus, Volker, "Profitability of PLS Banks Competing with Interest Banks: Problems and Prospects", Journal of Islamic Economics, Jeddah, Vol. 1, No. 1, 1983.

Siddiqi, Muhammad Nejatullah, "Some Economic Aspect of Mudarabah", Review of Islamic Economics, Vol. 1, No. 2, 1991.

Sundararajan, V., Marston, David and Shabsigh, Ghiath, "Monetary Operations and Government Debt Management Under Islamic Banking," IMF Working Paper 98/144, Washington DC, IMF, 1998.

Taylor, Mark, "Money and Financial Markets”, Oxford, Blackwell, 1991. 